\title{
Multiple Parameter Optimization for Maximization of Pectinase Production by Rhizopus sp. C4 under Solid State Fermentation
}

\author{
Shweta Handa *, Nivedita Sharma and Shruti Pathania \\ Microbiology Research Laboratory, Department of Basic Sciences, Dr Y S Parmar University of Horticulture and \\ Forestry, Nauni, Solan-173230, HP, India; niveditashaarma@yahoo.co.in (N.S.); \\ shrutipathania89@gmail.com (S.P.) \\ * Correspondence: shwetahanda137@gmail.com; Tel.: +91-94-5916-5432
}

Academic Editor: Marc Beauregard

Received: 19 January 2016; Accepted: 19 March 2016; Published: 4 May 2016

\begin{abstract}
A novel strain Rhizopus sp. C4 was isolated from compost for the production of pectinase. Cultivation of Rhizopus sp. C4 on orange peel substrate under various solid-state fermentation (SSF) conditions was evaluated for pectinase yield along with the enzyme activity profile as a potential, low-cost alternative to submerged-liquid fermentation. Response surface methodology (RSM) was employed to optimize various environmental parameters for pectinase production. Various parameters, namely temperature, moisture and incubation days, were studied statistically for a total of 20 runs using central composite design. The highest yield of the enzyme, i.e., $11.63 \mathrm{IU} / \mathrm{mL}$, was obtained from 1:3.5 moisture ratios in 7 days at $30^{\circ} \mathrm{C}$. The study demonstrated that optimization through RSM could improve the enzymatic characteristics and yield of the enzyme.
\end{abstract}

Keywords: pectinases; enzyme; optimization; pectinase; solid state fermentation

\section{Introduction}

Annually, about 34 million tons of citrus residues (peel, seeds) are produced from the processing of citrus fruits [1-3]. Although a part of these residues is applied in the diet of monogastric animals, its accumulation in the biosphere causes several environmental problems. At the same time, citrus peel can be an important and economical raw material to produce enzymes, mainly pectinase, by fermentative processes. This material contains almost all nutrients needed for microorganism growth, and several processes have been studied for the production of many important metabolites including enzymes [4]. Pectinases are enzymes that catalyze the hydrolysis of pectin (polygalacturonic acid) to galacturonic acid residues with extensive applications in extraction, clarification, and cloud stabilization of fruit juices, in degumming and retting of natural fibers. Pectinolytic enzymes that hydrolyze pectins find applications in various industrial processes. These enzymes are extensively used in the food and drink industries, chiefly in juice clarification because they are capable of reducing the viscosity of liquors during the clarification process $[5,6]$.

The production of PG by SSF employing agro-industrial residues and different microorganisms has been previously studied [7-13]. In SSF, it is necessary to consider that the produced metabolites remain in a solid matrix and, therefore, must be extracted by solid-liquid extraction or leaching. Therefore, this is the first step in any recovery and purification process that is intended for any desirable metabolite produced by SSF [14,15].

To reduce the cost of production, orange peel (pectic waste) as a substrate is used instead of synthetic cellulose due to their reasonable cost, high enzyme production capacity etc. The reduction in cost leads to an economically easy methodfor pectinase production. It is an important issue to deal 
with the residue, both for the comprehensive utilization of pectic resources and for the prevention of environmental pollution.

The conventional method for optimizing enzyme production via a"one variable at a time" approach involves varying a single independent variable while maintaining the others at a constant level. This one-dimensional approach is laborious and time-consuming especially for a large number of variables, and does not consider interactions among variables [16]. An alternative and more efficient approach is the use of statistical methods. Response surface methodology (RSM) involves afull factorial search by examining simultaneous, systematic and efficient variation of all components [17]. Statistical optimization not only allows forquick screening of alarge experimental domain, but also reflects the role of each of the components. RSM has already been successfully applied for the optimization of the media and the culture conditions in cultivation processes for the production of primary and secondary metabolites, i.e., amino acids, ethanol and enzymes [18].

In view of the potential industrial applications of pectinases, the present investigation was carried out to enhance the production of a pectinase from Rhizopus sp. C4 using citrus waste as acarbon source under SSF. Central composite design and RSM were employed to identify critical variables and optimize them for maximizing enzyme production in submerged fermentation.

\section{Materials and Methods}

\subsection{Substrates and Chemicals}

Various agro-waste residue of orange peels were purchased from the market of Nauni, Solan, Himachal Pradesh, India. Substrates were dried in the hot air oven at $60{ }^{\circ} \mathrm{C}$ up to $48 \mathrm{~h}$, ground to fine powder, sieved and kept in sterile containers until used. All chemicals used in this study were of analytical reagent (AR) grade and purchased from Sigma, Hi-Media Limited, SRL Pvt. Limited and Merck India Limited (Mumbai, India).

\subsection{Source of Fungal Inoculum}

A pectinase producing Rhizopus sp. C4 was isolated from pectic rich compost on Malt extract agar and the culture was maintained at $4{ }^{\circ} \mathrm{C}$.

\subsection{Solid State Fermentation}

Dried citrus peel ( $75 \%$ of the peel had a particle size ranging from $0.8 \mathrm{~mm}$ to $2 \mathrm{~mm}$, and the other $25 \%$ had a particle size between $2 \mathrm{~mm}$ and $3 \mathrm{~mm}$ ) was used and supplemented with the following substances in dry basis: $\mathrm{NH}_{4} \mathrm{NO}_{3} 0.43 \% ; \mathrm{Na}_{2} \mathrm{SO}_{4} 0.021 \% ; \mathrm{MgSO}_{4} 7 \mathrm{H}_{2} \mathrm{O} 0.077 \%$; $\mathrm{ZnSO}_{4} 7 \mathrm{H}_{2} \mathrm{O} 0.042 \%$; $\mathrm{KCl} 0.162 \%$; and $\mathrm{Ca}(\mathrm{OH})_{2} 0.011 \%$. Water was added to obtain $60 \%$ of initial humidity. Inoculation was made in a 1:10 (v/w) ratio in $10 \mathrm{~g}$ of wet solid media. Fermentations were carried out in a $250 \mathrm{~mL}$ wide-necked Erlenmeyer flask [19]. The cultures were incubated without agitation. All experiments were completed in triplicate.

\subsection{Polygalacturonase (PG) Activity}

PG was assayed by measuring the release of reducing sugars fromthe di-nitro-salicylic (DNS) method [20]. In this case, galacturonic acid (Sigma) was considered asimple sugar formed after pectin degradation. In a test tube, $0.9 \mathrm{~mL}$ of $0.5 \%(\mathrm{w} / \mathrm{v})$ pectin (Sigma) in $0.1 \mathrm{M}$ citrate buffer ( $\mathrm{pH} 4.0)$ was added to $0.1 \mathrm{~mL}$ of the diluted enzyme solution. After incubation for $15 \mathrm{~min}$ at $50{ }^{\circ} \mathrm{C}$, the reaction was stopped by the addition of $1 \mathrm{~mL}$ DNS, and the mixture was heated in boiling water for $5 \mathrm{~min}$. Distilled water $(5 \mathrm{~mL})$ was then added to each sample. Absorbances of the samples were read at $540 \mathrm{~nm}$. One unit of PG activity was defined as the amount of enzyme that liberates $1 \mu \mathrm{mol}$ of D-galacturonic acid per minute at $50{ }^{\circ} \mathrm{C}$ and $\mathrm{pH} 4.0$ [19]. 


\subsection{Experimental Design for Optimization}

RSM consists of a group of empirical techniques devoted to the evaluation of relations existing between a cluster of controlled experimental factors and the measured responses, according to one or more selected criteria. Prior knowledge and understanding of the process variables under investigation is necessary to achieve a realistic model. A three-factor CCD consisting of 20 experimental runs with three replications at the central point (Table 1) was used to optimize the independent variables, i.e., temperature, moisture and incubation days. A 20-factorial design was used in order to study the effect of temperature, moisture and incubation days. The statistical analysis of the results was performed using Design Expert ${ }^{\circledR}$ version 7.0 statistical software (Stat-Ease Inc, Minneapolis, MN, USA). Pectinase activity was analyzed using the analysis of variance (ANOVA) combined with the Fischer test to evaluate if a given term has a significant effect $(p \leqslant 0.05)$. The optimum levels of the variables were obtained by graphical and numerical analysis using Design Expert program.

Table 1. Levels of factors chosen for the experimental design.

\begin{tabular}{ccccc}
\hline \multirow{2}{*}{ Factors } & \multirow{2}{*}{ Unit } & Symbols & \multicolumn{2}{c}{ Actual Level Coded Factor } \\
\cline { 3 - 5 } & & & $\mathbf{- 1}$ & $\mathbf{1}$ \\
\hline Temperature & ${ }^{\circ} \mathrm{C}$ & $\mathrm{A}$ & 20 & 40 \\
Moisture & $\%$ & $\mathrm{~B}$ & $1: 1$ & $1: 5$ \\
Incubation Time & Days & $\mathrm{C}$ & 4 & 12 \\
\hline
\end{tabular}

\subsection{Model Validation}

The mathematical model generated during RSM implementation was validated by conducting check point studies. The experimentally obtained data were compared with the predicted resultand the prediction error was calculated.

\section{Results and Discussion}

\subsection{Cultural Characteristics of Fungal Isolate}

C4 showed the aseptate whitish mycelium in conidia were rough globular and tightly packed [20]. The organism was identified as Rhizopus sp. (Zygomycota: mucormycotina) based on its morphological and physiological characteristics. Figure 1 shows the microscopic examination of isolate $C 4$ under animaging compound microscope.

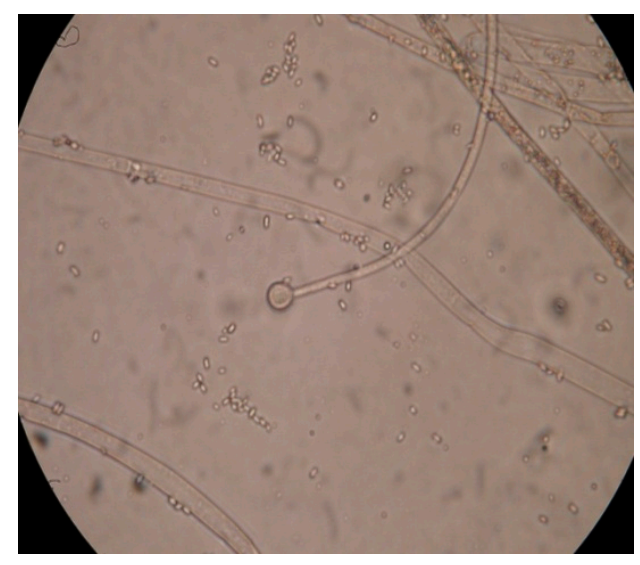

Figure 1. Microscopic examination of Rhizopus sp. C4. 


\subsection{Quantitative Estimation of Pectinase}

The quantitative estimation of pectinase was done by growing the culture of Rhizopus sp. C4 in media containing $1 \%$ pectin pectin (Sigma-Aldrich Co., St. Louis, MO, USA) using the standard protocol fromMiller [21] and itwas found to produce $4.12 \mathrm{IU} / \mathrm{mL}$ of enzyme. Pectinase production from Rhizopus sp. C4 was further optimized using thestatistical method.

\subsection{Optimization of Culture Conditions Using Response Surface Methodology}

The applied optimization approach is based on a central composite design and RSM. This method is one of the most important experimental designs used in process optimization studies [22]. The characterization of different factors for pectinase production was optimized by applying RSM. The statistical model was obtained using Central Composite Design (CCD) with three independent variables (i.e., temperature, moisture ratio, incubation days). A set of 20 experiments was performed. Pectinase production by Rhizopus sp. C4 is presented along with the predicted and observed responses in Table 2.

Table 2. Central composite design for the experimental design and predicted results for pectinase activity.

\begin{tabular}{cccccc}
\hline & & & & Enzyme Units (IU/mL) \\
\cline { 4 - 5 } Run & A:Temperature & B:moisture & $\begin{array}{c}\text { C:Incubation } \\
\text { Time }\end{array}$ & $\begin{array}{c}\text { Experimental } \\
\text { Values }\end{array}$ & $\begin{array}{c}\text { Predicted } \\
\text { Value }\end{array}$ \\
\hline 1 & & & 10.00 & 2.90 & 2.62 \\
2 & 40.00 & $1: 5.00$ & 7.00 & 11.63 & 11.61 \\
3 & 30.00 & $1: 3.50$ & 7.00 & 3.40 & 3.43 \\
4 & 30.00 & $1: 0.98$ & 12.05 & 1.93 & 2.60 \\
5 & 30.00 & $1: 3.50$ & 10.00 & 2.11 & 2.00 \\
6 & 20.00 & $1: 2.00$ & 4.00 & 3.50 & 11.63 \\
7 & 40.00 & $1: 2.00$ & 7.00 & 2.33 & 2.43 \\
8 & 30.00 & $1: 3.50$ & 7.00 & 11.63 & 11.61 \\
9 & 13.18 & $1: 3.50$ & 7.00 & 5.07 & 5.60 \\
10 & 30.00 & $1: 3.50$ & 7.00 & 0.90 & 5.16 \\
11 & 30.00 & $1: 6.02$ & 10.00 & 3.49 & 0.47 \\
12 & 20.00 & $1: 5.00$ & 10.00 & 2.11 & 3.18 \\
13 & 40.00 & $1: 2.00$ & 4.00 & 11.63 & 2.02 \\
14 & 40.00 & $1: 5.00$ & 4.00 & 1.70 & 1.61 \\
15 & 20.00 & $1: 2.00$ & 7.00 & 11.63 & 11.61 \\
16 & 30.00 & $1: 3.50$ & 7.00 & 2.40 & 2.43 \\
17 & 46.82 & $1: 3.50$ & 7.00 & 3.17 & 3.06 \\
18 & 30.00 & $1: 3.50$ & 4.00 & &
\end{tabular}

Solid-state fermentation has been advocated assuperior tosubmerged culture for the processing of agricultural and agro-based industrial wastes for generating higher enzyme yield and regulating the biosynthesis of particular composition of enzyme mixtures [23]. Solid state fermentation (SSF) is generally preferred because highly concentrated crude enzymes are obtained at low costs [24,25]. BesideSmF, SSF offers distinct advantages including economy of space needed for fermentation, simplicity of fermentation media, andno requirement for complex machinery, equipment orcontrol systems. Since the culture conditions in SSF are much more similar to the natural habitat of filamentous fungi, these are able to grow well and excrete large quantities of enzymes. Additionally, these processes are of special interest for countries like India with an abundance of agro-industrial wastes which can be used as cheap raw materials and it allows the utilization of wastes to produce useful products [26]. 


\subsection{Validation of the Model}

Moisture content is a crucial factor in any SSF process because this variable influences growth and biosynthesis of the microbe, as well as secretion of different metabolites such as enzymes. Low or high water content beyond its optimal content may affect enzyme production [27]. Optimization of moisture content could be employed for the management and the modification of microorganism metabolic processes [28]. In any SSF method, a vital factor is the incubation time because it has a largeeffect on growth and biosynthesis of the fungus, as well as the production of various primary and secondary metabolites, such as enzymes [29,30]. For optimum production of various enzymes by fungus, the temperatures optima of 25 to $37^{\circ} \mathrm{C}$ range have been reported [31,32].

ANOVA for the refined model is summarized in Table 3. The regression model for pectinase production was highly significant $(p<0.01)$ with a satisfactory value of determination co-efficient $\left(R^{2}=0.9883\right)$ indicating $98.83 \%$ variability in the response could be explained by second order polynomial equation given below.

Table 3. Analysis of variance (ANOVA) for theresponse surface quadratic model obtained from experimental designs.

\begin{tabular}{cccccc}
\hline Source & Sum of Squares & DF & Mean Value & F Square & Prob $>$ F \\
\hline Model & 300.42 & 9 & 33.38 & 170.45 & $<0.0001^{*}$ \\
A & 0.53 & 1 & 0.53 & 2.72 & 0.1332 \\
B & 5.66 & 1 & 5.66 & 28.88 & $0.0004^{*}$ \\
C & 0.25 & 1 & 0.25 & 1.30 & 0.2835 \\
A2 & 148.07 & 1 & 148.07 & 756.08 & $<0.0001^{*}$ \\
B2 & 85.90 & 1 & 85.90 & 438.65 & $<0.0001^{*}$ \\
C2 & 131.55 & 1 & 131.55 & 671.73 & $<0.00011^{*}$ \\
AB & 0.50 & 1 & 0.50 & 2.55 & 0.1445 \\
AC & 5.44 & 1 & 5.44 & 27.80 & $0.0005^{*}$ \\
BC & 3.67 & 1 & 3.67 & 18.75 & 0.0019 * \\
Residual & 1.76 & 9 & 0.20 & & \\
Lack of Fit & 1.76 & 5 & 0.35 & & \\
Pure Error & 0.000 & 4 & 0.000 & & \\
Cor Total & 302.18 & 18 & &
\end{tabular}

The fitted equation (in terms of coded values) for pectinase production (Y) is expressed as:

$$
\mathrm{Y}=+11.61-0.20 \mathrm{~A}+0.64 \mathrm{~B}-0.14 \mathrm{C}-3.29 \mathrm{~A}^{2}-2.51 \mathrm{~B}^{2}-3.10 \mathrm{C}^{2}-0.25 \mathrm{AB}-0.82 \mathrm{AC}+0.68 \mathrm{BC}
$$

where $\mathrm{Y}$ is enzyme production, $\mathrm{A}$ is temperature, $\mathrm{B}$ is moisture ratio and $\mathrm{C}$ is incubation time (days). The $\mathrm{R}^{2}$ value is always between 0 and 1 . The closer the $\mathrm{R}^{2}$ is to 1.0 , the stronger the model and better it predicts the response [33].

The justification of the variability in observed response values by the experimental factors (variables) and their interactions was measured by $\mathrm{R}^{2}$ (coefficient of determination). The predicted $R^{2}$ value of 0.9545 by the model in close agreement with actual $R^{2}$ value 0.9883 implied that the fitted linear, interaction and quadratic terms could elucidate $98.83 \%$ of variation, showing satisfactory representation of the process model. The model F-value and probality value $\left(\mathrm{P}_{\text {model }}>\mathrm{F}\right)$ of 170.45 and $<0.0001$ respectively for pectinase production indicate that the applied model is highly significant. Values of Prob $>$ F less than 0.05 indicate model terms are significant. For pectinase production $B, A^{2}$, $\mathrm{B}^{2}, \mathrm{C}^{2}, \mathrm{AC}, \mathrm{BC}$ are significant models. The precisionand reliability of the conducted experiments were confirmed by the lower value of coefficient of variation $(\mathrm{CV})$ of 8.50 . The measured signal-to-noise ratio indicated adequate precision. A desirable ratio should be greaterthan 4 . The model ratio of 34.689 was found to be greater than 4 , indicating an adequate signal that can be used for design space navigation. The standard deviation value 0.44 indicated that the model showed strong compliance with the 
predicted response.This model can be used to navigate the design space. The optimum experimental conditions were obtained by the differentiation of the quadratic model to achieve maximum enzyme production. The optimum conditions were $\mathrm{A}=30^{\circ} \mathrm{C}, \mathrm{B}=1: 3.5$ and $\mathrm{C}=7$ days. The predicted enzyme production corresponding to these levels was $11.63 \mathrm{IU} / \mathrm{mL}$. A 3-fold increase in the enzyme activity was observed after optimizing the factors using RSM and it was found tobea valid model for the optimization processes.

Similar to our results, a 1.5-fold increase in pectinolytic enzymes secretion by Kluyveromyces wickerhamii was attained when $\mathrm{pH}$, temperature and incubation period were optimized by RSM [34]. A 70\% increase in a-amylase production by Geobacillusthermoleovorans was achieved using RSM [35].

Comparative effects of any two variables were explained by contour plots while holding the other factors fixed at their central point values. From response surface (3D) and contour plots (2D), the interactive effects of experimental factors on pectinase synthesis were determined. Figure 2 shows athree-dimensional diagram and contour plot of calculated response surface from the interaction between various variables.

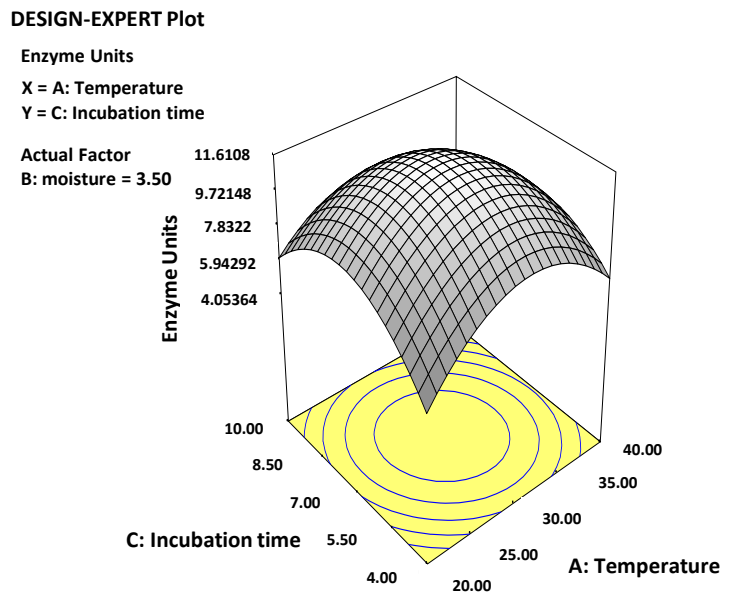

(a)

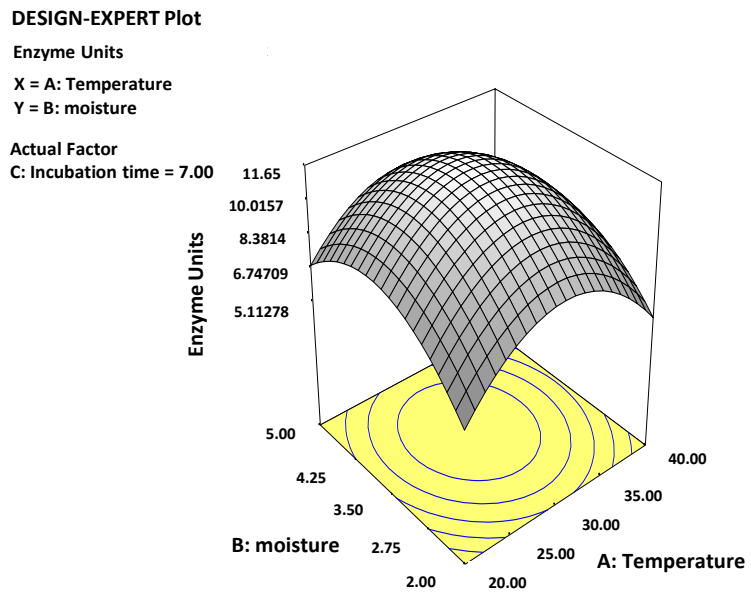

(b)

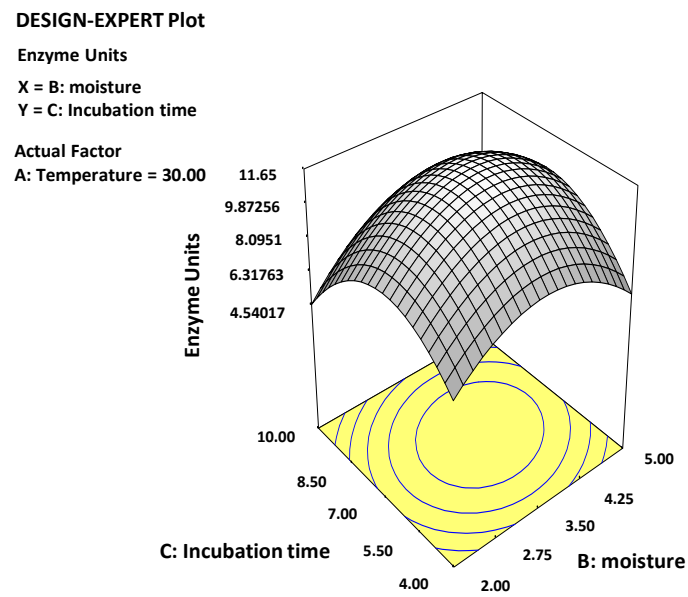

(c)

Figure 2. Response surface graphs showing interaction between various process parameters for enhanced pectinase production from Rhizopus sp. C4. (a) Incubation time and temperature; (b) moisture and temperature; (c) incubation time and moisture.

Temperature, moisture content and incubation days showed quadratic effects on the production of pectinase. The interaction effects of three independent variables were significant through interaction of 
all of these three factors for pectinase production. The changes brought about by physical characteristics are an important design tool for process development of the SSF. By changing the physical attributes, the expression level of theenzyme can be varied such that physiochemical characteristics become the reading force in directing synthesis of pectinase enzyme system in SSF. Figure 3 shows thenormal probability withinternally studentized residuals for Rhizopus sp. C4.

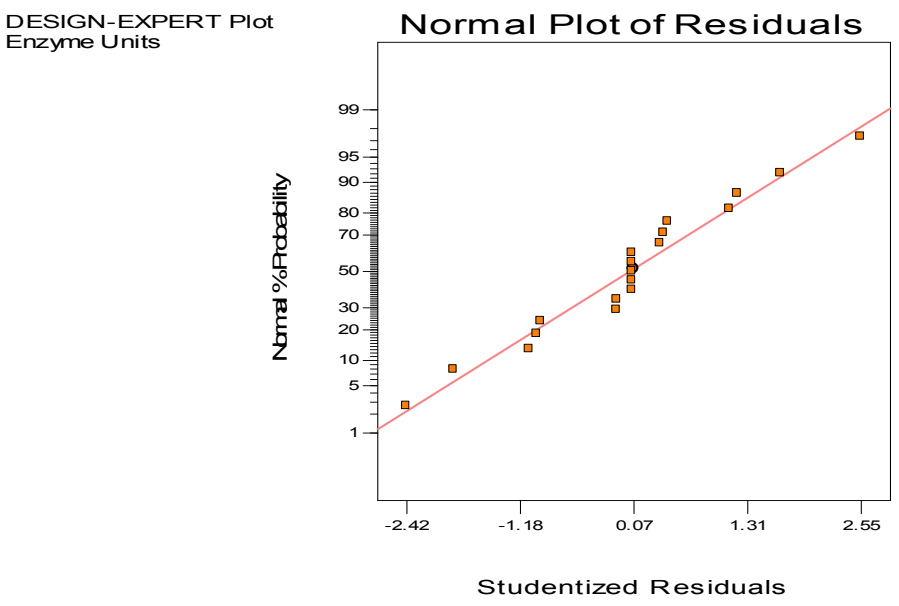

Figure 3. Normal probability withinternally studentized residuals for Rhizopus sp. C4.

\section{Conclusions}

Rhizopus sp. C4 is a promising organism for production of pectinase, and statistical design like RSM can be used for optimization of process parameters and their interactions. The research results indicated that RSM not only helps us locate the optimum conditions of the process variables in order to enhance the maximum pectinase enzyme production, but also proves to be well suited to evaluating the main effectsand interaction effects of the process variables on pectinase production from waste agricultural residues. Citrus waste was found tobea promising waste for pectinase production, whichelps in decreasing both pollution and the cost of enzyme production.

Acknowledgments: The authors are very thankful to the Department of Basic Sciences, Microbiology section, UHF, Nauni, Solan for providing laboratory facilities and to everyone who contributed to the completionof this study.

Author Contributions: Shweta Handa and Shruti Pathania performed the experiments, analyzed the data and wrote the paper; and Nivedita Sharma has conceived and designed the experiments.

Conflicts of Interest: The authors declare no conflict of interest.

\section{References}

1. Huang, Y.S.; Ho, S.C. Polymethoxy flavones are responsible for the anti-inflammatory activity of citrus fruit peel. Food Chem. 2010, 119, 868-873. [CrossRef]

2. Martín, M.A.; Siles, J.A.; Chica, A.F.; Martín, A. Biomethanization of orange peel waste. Bioresour. Technol. 2010, 101, 8993-8999. [CrossRef] [PubMed]

3. Anwar, F.; Naseer, R.; Bhanger, M.I.; Ashraf, S.; Talpur, F.N.; Aladedunye, F.A. Physico-chemical characteristics of citrus seeds and seed oils from Pakistan. J. Am. Oil Chem. Soc. 2008, 85, 321-330. [CrossRef]

4. Palit, S.; Banerjee, R. Optimization of extraction parameters for recovery of $\alpha$ - amylase from the fermented bran of Bacillus circulans GRS313. Braz. Arch. Biol. Technol. 2001, 44, 107-111. [CrossRef]

5. Oszmianski, J.; Wojdyło, A.; Kolniak, J. Effect of pectinase treatment on extraction of antioxidant phenols from pomace, for the production of pure enriched cloudy apple juices. Food Chem. 2011, 127, 623-631. [CrossRef] [PubMed] 
6. Pedrolli, D.B.; Gomes, E.; Monti, R.; Cano-Carmona, E. Studies on productivity and characterization of polygalacturonase from Aspergillusgiganteus submerged culture using citrus pectin and orange waste. Appl. Biochem. Biotechnol. 2008, 144, 191-200. [CrossRef] [PubMed]

7. Kumar, Y.S.; Varakumar, S.; Reddy, O.V.S. Production and optimization of polygalacturonase from mango (Mangiferaindica L.) peel using Fusariummoniliforme in solid state fermentation. World J. Microbiol. Biotechnol. 2010, 26, 1973-1980. [CrossRef]

8. Mamma, D.; Kourtoglou, E.; Christakopoulos, P. Fungal multienzyme production on industrial by-products of the citrus-processing industry. Bioresour. Technol. 2008, 99, 2373-2383. [CrossRef] [PubMed]

9. Tari, C.; Gögus, N.; Tokatli, F. Optimization of biomass, pellet size and polygalacturonase production by Aspergillussojae ATCC 20235 using response surface methodology. Enzym. Microb. Technol. 2007, 40, 1108-1116. [CrossRef]

10. Botella, C.; Diaz, A.; de Ory, I.; Webb, C.; Blandino, A. Xylanase and pectinase production by Aspergillus awamori on grape pomace in solid state fermentation. Process Biochem. 2007, 42, 98-101. [CrossRef]

11. Kuhad, R.C.; Kapoor, M.; Rustagi, R. Enhanced production of an alkaline pectinase from Streptomyces sp. RCK-SC by whole-cell immobilization and solid-state cultivation. World J. Microbiol. Biotechnol. 2004, 20, 257-263. [CrossRef]

12. De Gregorio, A.; Mandalari, G.; Arena, N.; Nucita, F.; Tripodo, M.M. SCP and crude pectinase production by slurry-state fermentation of lemon pulps. Bioresour. Technol. 2002, 83, 89-94. [CrossRef]

13. Silva, D.; Martins, E.S.; Silva, R.; Gomes, E. Pectinase production by Penicilliumviridicatum rfc3 by solid state fermentation using agricultural wastes and agro-industrial by-products. Braz. J. Microbiol. 2002, 33, 318-324. [CrossRef]

14. Castilho, L.R.; Alves, T.L.M.; Medronho, R.A. Recovery of pectolytic enzymes produced by solid state culture of Aspergillusniger. Process Biochem. 1999, 34, 181-186. [CrossRef]

15. Gupta, S.; Kapoor, M.; Sharma, K.K.; Nair, L.M.; Kuhad, R.C. Production and recovery of an alkaline exo-polygalacturonase from Bacillus subtilis RCK under solid-state fermentation using statistical approach. Bioresour. Technol. 2008, 99, 937-945. [CrossRef] [PubMed]

16. Kumari, S.K.; Babu, I.S.; Rao, G.H. Process optimization for citric acid production from raw glycerol using response surface methodology. Indian J. Biotechnol. 2008, 7, 496-501.

17. Sharma, D.C.; Satyanarayana, T. Production and application of pectinolytic enzymes of Sporotrichum thermophile and Bacillus pumilus. In Biotechnological Approaches for Sustainable Development; Reddy, M.S., Khanna, S., Eds.; Allied Publishers Pvt. Ltd: New Delhi, India, 2004; pp. 164-169.

18. He, G.Q.; Kong, Q.; Ding, L.X. Response surface methodology for optimizing the fermentation medium of Clostridium butyricum. Lett. Appl. Microbiol. 2004, 39, 363-368. [CrossRef] [PubMed]

19. Rodríguez-Fernández, D.E.; Rodríguez-León, J.A.; de Carvalho, J.C.; Sturm, W.; Soccol, C.R. The behavior of kinetic parameters in production of pectinase and xylanase by solid-state fermentation. Bioresour. Technol. 2011, 102, 10657-10662. [CrossRef] [PubMed]

20. Breed, R.S.; Murray, E.G.D.; Smith, N.R. Bergey's Manual of Determinative Bacteriology, 7th ed.; The Williams and Wilkins Co., American Society of Microbiology: Baltimore, MD, USA, 1957.

21. Miller, G.L. Use of dinitrisosalicilic acid reagent for determination of reducing sugars. Anal. Chem. 1959, 31, 426-428. [CrossRef]

22. Myer, R.; Montgomery, D.C. Response Surface Methodology; John Wiley and Sons Inc.: New York, NY, USA, 2002.

23. Patil, S.R.; Dayanand, A. Optimization of process for the production of fungal pectinases from deseeded sunflower head in submerged and solid state conditions. Bioresour. Technol. 2006, 97, 2340-2344. [CrossRef] [PubMed]

24. Kashyap, D.R.; Soni, S.K.; Tewari, R. Enhanced production of pectinase by Bacillus sp. DT7 using solid state fermentation. Bioresour. Technol. 2003, 88, 251-254. [CrossRef]

25. Silva, D.; Tokuioshi, K.; da Silva Martins, E.; Da Silva, R.; Gomes, E. Production of pectinase by solid-state fermentation with Pencilliumviridicatum RFC3. Process Biochem. 2005, 40, 2885-2889. [CrossRef]

26. Castilho, L.R.; Medronho, R.A.; Alves, T.L.M. Production and extraction of pectinase obtained by solid state fementation of agroindustrial residues with Aspergillusniger. Bioresour. Technol. 2000, 71, 45-50. [CrossRef]

27. Yasmeen, Q.; Asgher, M.; Sheikh, M.A.; Nawaz, H. Optimization of ligninolytic enzymes production through response surface methodology. BioResource 2013, 8, 944-968. [CrossRef] 
28. Pandey, A.; Ashakumari, L.; Selvakumar, P.; Vijayalakshami, K.S. Influence of water activity on growth and activity of Aspergillusniger for glucoamylase production in solid state fermentation. World J. Microbiol. Biotechnol. 1994, 10, 485-486. [CrossRef] [PubMed]

29. Vaithanomasat, P.; Apiwatanapiwat, W.; Petchoy, O.; Chedchant, J. Production of ligninolytic enzymes by white-rot fungus Datronia sp. KAPI0039 and their application for reactive dye removal. Int. J. Chem. Eng. 2010, 2010, 162504:1-162504:6.

30. Lee, C.K.; Darah, I.; Ibrahim, C.O. Production and optimization of cellulose enzyme using Aspergillus niger USM AI 1 and comparison with Trichodermareesei via solid state fermentation system. Biotechnol. Res. Int. 2011, 2011, 658493:1-658493:6. [CrossRef] [PubMed]

31. Zadrazil, F.; Karma, D.N.; Isikuemhen, O.S.; Schuchardt, F. Bioconversion of lignocellulosic into ruminant feed with white rot fungi. J. Appl. Anim. Res. 1999, 10, 105-124. [CrossRef]

32. Tripathi, M.; Mishra, K.A.S.; Mishra, A.S.; Vaithiyanathan, S.; Prasad, R.; Jakhmola, R.C. Selection white rot basidiomycetes for bioconversion of mustard (Brassica compestris) straw under SSF into energy substrate for rumen microorganism. Lett. Appl. Microbiol. 2008, 46, 364-370. [CrossRef] [PubMed]

33. Uma Maheswar Rao, J.L.; Satyanarayana, T. Statistical optimization of a high maltose-forming, hyperthermostable and $\mathrm{Ca}^{2+}$-independent amylase production by an extreme thermophile Geobacillus thermoleovorans using response surface methodology. J. Appl. Microbiol. 2003, 95, 712-718. [CrossRef] [PubMed]

34. Moyo, S.; Gashe, B.A.; Collison, E.K.; Mpuchane, S. Optimizing growth condition for the pectinolytic activity of Kluyveromyceswickerhamii by using response surface methodology. Int. J. Food Microbiol. 2003, 15, 87-100. [CrossRef]

35. Maciel, M.D.H.C.; Herculano, P.N.; Porto, T.S.; Teixeira, M.F.S.; Moreira, K.A.; de Souza-Motta, C.M. Production and partial characterization of pectinase from forage palm by Aspergillusniger URM4645. Afr. J. Biotechnol. 2011, 10, 2469-2475.

(C) 2016 by the authors; licensee MDPI, Basel, Switzerland. This article is an open access article distributed under the terms and conditions of the Creative Commons Attribution (CC-BY) license (http://creativecommons.org/licenses/by/4.0/). 